\title{
A REVIEW OF THE FISHES OF JAPAN BELONGING TO THE FAMILY OF HEXAGRAMMIDE.
}

\author{
By David Starr Jordan and Edwin Chapin Starks, \\ Of the Leland Stanford Junior University.
}

In this paper is given a review of the fishes of the family of Hexagrammidæ, Rock Trout or Greenlings, in Japanese Ainame, known to inhabit the waters of the Japanese Empire. It is based on material in the museum of Leland Stanford Junior University and in the United States National Museum.

\section{Family HEXAGRAMMID E.}

Body elongate, covered with small scales, which are ctenoid or cycloid; head conical, scaly, the cranium without spinous ridges above; preopercle usually more or less armed, sometimes with entire edges; third suborbital developed as a bony stay articulating with the preopercle; acute teeth in the jaws, and usually on vomer or palatines; nostril single on each side, the posterior opening reduced to a minute pore; gills 4, a long slit behind the fourth; gill membranes separate or united, usually free from the isthmus; branchiostegals 6 or 7 ; pseudobranchiæ well developed. Dorsal fin continuous or divided, the anterior half of many slender spines; anal fin long, with or without spines; ventrals 1 to 5 , inserted more or less behind the pectorals; pectorals broad, usually with procurrent base, the lower rays simple, more or less thickened; lateral line present, sometimes several series of pores developed; vertebræ numerous; pyloric cæca. Carnivorous fishes, mostly of large size, living in kelp and about rocks in the North Pacific; some of them highly valued as food

a Dorsal fins contiguous or connected.

$b$ Anal fin very long, its rays 20 or more.

c Anal fin without spines.

d Hexagrammina: Gill membranes broadly united; mouth moderate, the jaws with an outer series of stronger teeth, but no canines.

e Lateral line single on each side............................... ee Lateral lines 4 or more on each side.

$f$ Dorsal fin with the spines separated from the soft rays by a deep noteh.

Hexagrammos, 2. 


\section{AGRAMMUS Günther.}

Agrammus GüNTHeR, Cat. Fish, 1860, II, p. 94 (agrammus=schlegeli).

Head and body compressed, rather elongate. Scales small, ctenoid. Lateral line single. Bones of head not armed. Edge of preopercle entire. Dorsal continuous, elongate, with 17 or 18 spines and 21 or 22 soft rays; a shallow notch between spinous and rayed portions. Ventral with 1 spine and 5 soft rays. Teeth small, on jaws and vomer, the outer row of teeth on jaws enlarged; palatines toothless. A flap above orbit and one at nape. Branchiostegals 6 .

Japanese fishes, differing from Hexagrammos mainly in the undivided lateral line.

( $\ddot{\alpha}$, without; $\gamma \rho \alpha \mu \mu \dot{\eta}$, line.)

I. AGRAMMUS AGRAMMUS (Schlegel).

KUJIME.

Labrax agrammus Schlegkl, Fauna Japonica, Poiss., 1843, a p. 56; Nagasaki. Agrammus agrammus JoRdAn and SNyder, Check List., 1801, p. 101; Yokohama. Agrammus schlegeli Günther, Cat. Fish, II, 1860, p. 94; Japan.-Steindachner and Dönerlein, Fische Japans, IV, 1887, p. 266; Tokyo.-Ishikawa, Prel. Cat., 1897, p. 51; Tokyo.

Head 4 in length without caudal, depth $3 \frac{1}{2}$. Dorsal XVII or XVIII, 21 or 22 ; anal 19 . Scales 86 . Eye 5 in head; maxillary $3 \frac{1}{6}$; interorbital 6 .

Maxillary reaching just past front of eye. Outer row of teeth enlarged in both jaws; vomer with rather coarse teeth; palatine toothless. A short fringed flap over eye and a shorter similar one at nape.

Pectoral scarcely reaching to tips of ventrals; its posterior edge is broadly rounded; the seventh to tenth rays from the top the longest, $1_{10}^{1}$ in head. Ventrals reaching two-thirds the distance from their base to front of anal. Notch in dorsal not deep; the fifth spine 2 in head; the last spine $4 \frac{1}{4}$; the fourth soft ray equal in length to the fifth spine; the spines or rays not produced beyond the membrane. Tips of anal rays free; the length of the fourth ray equal to the seventeenth ray, $2 \frac{3}{5}$ in head. Caudal truncate or very slightly rounded.

Scales strongly ctenoid on body and top of head, slightly rough on side of head behind eye, cycloid on cheek, opercle, breast, and in front of pectoral. Snout, maxillary, mandible, suborbitals, including stay, interopercle and branchiostegal region naked. There are 50 scales in an oblique series running upward and forward from front of anal to dorsal, 18 of these between lateral line and dorsal. Small scales on extreme base of spinous dorsal between spines, and on basal third of soft dorsal; basal third or fourth of pectoral and over half of caudal with scales; anal entirely naked. 
Color in spirits: head and body brown, marbled with irregular spots of dark brown not of the same shape on different examples, but placed with some uniformity; the dark areas darker at edges; a dark bar between eyes followed by a light area; a dark spot at nape, united with one at front of dorsal, at its lower edge inclosing a light spot in front of dorsal; a dark spot above pectoral and behind opercle flap; a dark spot under anterior third of dorsal running up on dorsal; one under posterior fourth of spinous dorsal, much broken up and running irregularly across body, sometimes running into the one under anterior third of dorsal inclosing a spot of light color above, a spot under front of dorsal and one under middle, both usually joined below with a larger spot, which is continued down nearly to anal fin; another spot under posterior end of soft dorsal extending up on the fin and margined behind with light; a broken bar across caudal peduncle; caudal crossed with alternate bars of dark and light, the former the broader and about 5 in number; sometimes many of the scales on lower part of sides have white spots on their center; dark bars radiating from eye, one to each end of maxillary, a couple downward and backward across cheek, the upper one being above suborbital stay, one straight backward, and one to nape; lower part of head sometimes with 4 or 5 light spots as large as pupil; anal obliquely crossed by alternate light and dark bars, very conspicuous in the young; these variable in number; the dark bars from 5 to 8 ; ventrals dusky; a dark spot at base of pectoral; the fin crossed by inconspicuous irregular bars.

Specimens were taken in abundance at Tokyo, Aomori, and Hakodate. It is generally common throughout middle Japan, especially in bays of rocky bottom. It is a common species in the markets, although much less abundant than the "fat greenling," Hexagrammos otakii.

\section{HEXAGRAMMOS (Steller) Tilesius.}

Dodecagrammos Steller, in Krascheninnikof, Reise in Kamchatka, 1750, p. 175 (nonbinomial).

Hexagrammos, Steller, manuseript.

Hexagrammos Trlesius, Act. Acad. Petrop., II, 1809, p. 335 (asper).

Labrax (Steller MS.) Pallas, Mém. Acad. Petersb., II, 1810, p. 382 (lagocephalus).

Lebius (Steller MS.) Pallas, Zoographia Rosso-Asiat., III, 1811, p. 279 (superciliosus).

Chirus (Steller MS.) PALlas, Zoographia Rosso-Asiat., III, 1811, p. 279 (superciliosus).

Chirus Cuvier, Règne Anim, 2 d ed., II, 1829, p. 249 (superciliosus).

Chiropsis Girard, U. S. Pac. R. R. Surv., X, Fishes, 1858, p. 42 (constellatus).

Octogrammus Bleek ER, Versl. Ak. Amat., VI, 1874, p. 1370 (octogrammus).

Grammatopleurus Gild, Proc. Ac. Nat. Sci. Phil., 1861, p. 166 (lagocephatus):Acantholebius Grlu, Proc. Ac. Nat. Sci. Phil., 1861, p. 168 (thently increased)

Body oblong, somewhat compressed. Head suconds of moderate profile. Mouth rather small, horizuntal; jaws with bands of moderate 
sized, conical teeth, the outer row enlarged; teeth on vomer, and usually but not always a small patch on the prlatines; preopercle unarmed; a fringed supraorbital cirrus, large or small; gill membranes broadly connected, free from the isthmus; gill-rakers short, tuberclelike. Scales small, mostly ctenoid, sometimes partly or wholly cycloid; head more or less scaly, without spines; nostril simple, round, with a pore behind it. Lateral lines usually 5 on each side. Dorsal fin long, with a deep emargination between the spines and the soft rays; dorsal spines slender, 19 to 22 in number; anal fin elongate, with a single rudimentary spine; rays of pectorals and anal exserted and almost simple; pectoral rounded with broad, procurrent base, the rays thick; ventrals well developed, placed at a considerable distance behind the root of the pectorals; caudal subtruncate. Branchiostegals, 6. Pyloric cæca numerous (about 13.) No air bladder. Species of rather large size and bright coloration; abundant in the North Pacific on both shores, extending southward from Bering Sea.

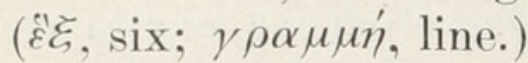

a Cheeks not fully scaled, the suborbital stay at least naked; no occipital flaps.

$b$ Fourth lateral line not forked and not extending past tips of ventrals.

c Fifth lateral line joining median line on breast ...................... otakii, 2.

$c c$ Fifth lateral line not joined to median line on breast ............... aburaco, 3.

$b b$ Fourth lateral line forked in front of ventrals; the upper branch not extending to tips of ventrals; back with obscure dark -bands ........... . octogrammus, 4 .

$b b b$ Fourth lateral line running to above middle of anal; elevated about five scales above fifth lateral line; back with dark spots and cloudings ...lagocephalus, 5 .

\section{HEXAGRAMMOS OTAKII Jordan and Starks.}

\section{ABURA AINAME (FAT GREENLING).}

Labrax hexagrammus Schlegel, Fauna Japonica, Poiss., 1843, p. 53, pl. xxIII, Nagasaki (not of Pallas).

Chirus hexagrammus Bleeker, Verh. Bat. Gen. Japan, about 1867, p. 80.-IshiKawa, Prel. Cat., 897, p. 51; Tokyo, Kii.

Hexagrammus asper Steindachner and Döderlein, Fische Japans, IV, 1887, p. 266; Tokyo (not of Pallas).

Hexagrammos otakii Jordan and Starks, Proc. Calif. Acad. Sci., 1895, p. 800; Tokyo.-Jordan and Gilbert, Rept. Fur Seal Expl., III, 1898, p. 453; Tokyo.-Jordan and Evermann, Fish. N. M. Am., II, 1898, p. 1867; Tokyo.

Head $3 \frac{3}{4}$ in length without caudal. Depth $4 \frac{1}{4}$ to $4 \frac{1}{2}$. Dorsal XIX or XX, 22; anal 21 to 23 . Series of scales running downward and backward below third lateral line, 107 to 112 . Eye $4 \frac{4}{5}$ in head; maxillary $2 \frac{4}{5}$ to 3 ; interorbital space (bone only) $6 \frac{1}{2}$.

Maxillary reaching past front of eye scarcely to front of pupil. Outer teeth enlarged and rather uneven on both jaws; palatines toothless; vomer with teeth similar to the smaller teeth on jaws; the band on premaxillaries wider in front than on front of mandible. A short fringed flap above eye, but little longer than diameter of pupil; a pair 
of small tentacles on nape.

(We have one specimen out of 50 or 60 without tentacles at nape.)

The notch between spines and rays of dorsals not deep; the last spine not longer than the one preceding it; the sixth spine $2 \frac{1}{4}$ in head, higher than the longest rays, which are $2 \frac{3}{5}$ in head. Pectoral scarcely reaching to tips of ventrals, not nearly to vertical from vent; the sixth ray from the top the longest, $1 \frac{1}{5}$ in head; 17 rays, divided toward ends only once. Fifth anal ray 3 in head. Ventrals rather long and pointed, reaching $\frac{3}{5}$ or $\frac{2}{3}$ of distance from their base to front of anal. Caudal concave with fin closed.

Scales everywhere except on head, nape and breast rather strongly ctenoid; 62 scales in a series from front of anal to dorsal in a series running upward and forward, distributed as follows: 5 from front of anal to fifth lateral line; 35 to third; 14 to second; 5 to first; and 3 to dorsal. First lateral line rumning from front of dorsal or a little before it to a point varying from under anterior third of soft dorsal to posterior fourth. Second lateral line running from a little in front of dorsal to upper part of caudal base; third line from upper end of gill opening to middle of caudal base. Fourth line short, composed of very small pores, running from gill opening, nearly touching pectoral base, to across base of ventral, not reaching to tip of ventral; often it does not extend anteriorly past ventral base. Median line on breast dividing under distal fourth of ventrals and running to lower part of caudal base; these two parts join median line at rather an obtuse angle; when they join it anterior to distal third or fourth of ventrals they form an acute angle; their point of union is never much past middle of ventrals. Scales on top of head to a little in front of eyes. Cheeks closely scaled below suborbitals and preorbital; opercle completely scaled and a few scales on upper part of interopercle. Snout, maxillary, preorbital, suborbitals, including suborbital stay, mandible, the greater part of interopercle and branchiostegals all naked.

Color in spirits light brown, lighter below, marked on back and sides with dark brown quadrate blotches; on back these are arranged as follows: One across interorbital space, one at nape, one under front of dorsal, two equally distributed under spinous dorsal, one under first soft rays, one under middle soft rays, one under last rays, one across caudal peduncle, and traces of one across base of caudal rays; dorsal mottled with dark brown; a darker spot on tips of last spines; pectoral crossed and mottled with bands of dark brown, a dark spot at base of rays; tips of anal rays white, a dark streak bordering fin inside of white border from which 7 or 8 bands cross rays obliquely to base of fin, leaving white intervals between them; many white spots often scattered irregularly over side, and a few larger ones on pectoral; ventrals dusky. 
Here described from the 4 typical specimens, the longest $23 \mathrm{~cm}$. in length.

Many specimens were taken by Jordan and Snyder at Tokyo, Aomori, Hiroshima, Nagasaki, Hakodate, Kobe, and Tsuruga. It is abundant throughout Japan, but is not known to the northward of Hakodate. (Named for Keinosuke Otaki.)

3. HEXAGRAMMOS ABURACO Jordan and Starks, new species.

ABURAKO (FAT THING).

Head $3 \frac{1}{2}$ in length without caudal; depth $4 \frac{1}{4}$. Dorsal XIX, 22; anal 21. Scales below lateral line 110 to 120 . Eye $4 \frac{3}{4}$ in head; maxillary $2 \frac{5}{6}$; interorbital width (bone only) $6 \frac{1}{2}$.

Maxillary reaching to front of pupil. Outer teeth enlarged in both jaws; vomer with teeth; palatines toothless. A short flap above eye, fringed at the edge; its length is scarcely equal to diameter of pupil; a pair of very small tentacles at nape.

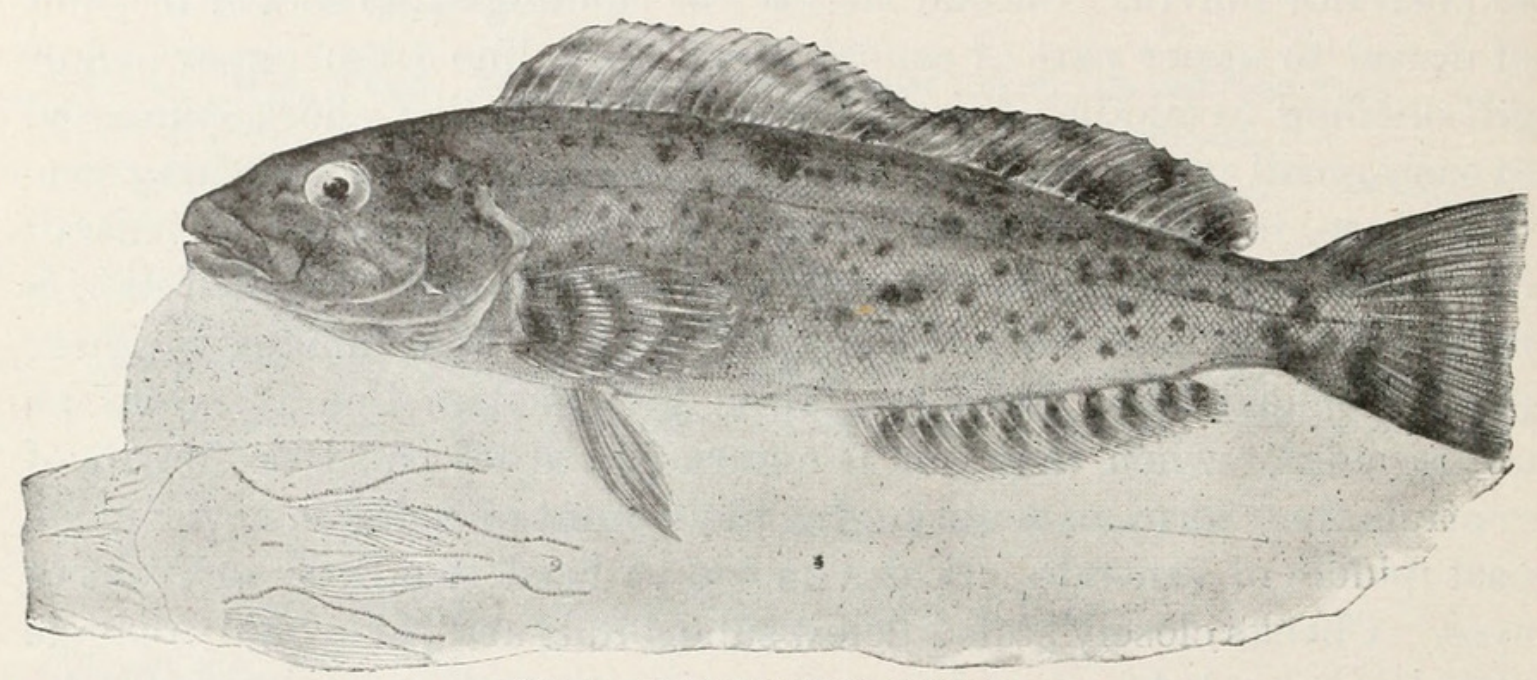

Fig. 1.-Hexagramios abUraco.

Notch between dorsals shallow, the last spine not longer than the one preceding it; the sixth spine $2 \frac{3}{4}$ in head; the last 4 . Third dorsal ray 3 in head; tips of last dorsal rays on the same vertical with tips of last anal rays; origin of anal midway between tip of snout and tips of median caudal rays. Pectoral not quite reaching to tips of ventrals; it has 18 rays, their tips not much branched; the seventh ray from the top the longest, $1 \frac{2}{5}$ in head. Ventrals reaching five-eighths of distance from their base to front of anal. Caudal concave when fin is closed. In life sometimes bright rusty red with pearly spots; fins rusty red, the lower dusky purplish, the red often replaced by dull green.

Scales everywhere strongly ctenoid, except on head, breast, and in front of pectoral. Top of head to front of eyes, cheeks below and above suborbital stay, and opercle, with fine cycloid scales. Snout, maxillary, preorbital, suborbitals, including suborbital stay, mandible, interopercle, and branchiostegals naked. Scales on base of pectoral 
and caudal; and on membrane between soft dorsal rays; other fins scaleless. From front of anal to dorsal in a series running upward and forward there are 67 scales, distributed as follows: 6 seales from first anal ray to fifth lateral line; 41 to third line; 12 to second line; 5 to first line; and 3 to dorsal. First lateral line running from front of spinous dorsal to under middle of soft dorsal; the second from slightly in front of spinous dorsal to upper edge of caudal; the third from upper end of gill opening to middle of caudal; the fourth very short, not extending past ventral tips; the fifth beginning a short distance behind ventral base and running to lower edge of caudal; it does not join its fellow of the opposite side, nor does it join the median line of the breast; the median line starts a short distance in front of ventrals and running between them reaches nearly to their tips.

Color in spirits: Brown on sides and back, becoming lighter below; no definite markings on body; one or two specimens show traces of dark blotches on sides; dorsal irregularly mottled with dusky; anal sometimes obliquely crossed with 7 or 8 dusky bars; sometimes uniformly dark siate color, the tips of the rays white; pectoral with faint, dusky bars following the contour of the posterior edge of the fin; ventrals dusky. In life sometimes bright rusty red with pearly spots; fins rusty red, the lower dusky purplish, the red often replaced by dull green.

This species differs from Hexagrammos otakï chiefly in not having the fifth lateral lines connected with each other, nor with the median line on breast.

The type is from Tokyo, and is 225 millimeters in length. One cotype from Nagasaki, and two from Hakodate.

The type is numbered 7374, Ichthyological Collections, Leland Stanford Junior University Museum. Cotypes are in the U. S. Nat. Mus.

(Name from the vernacular, Aburako: fat thing.)

\section{HEXAGRAMMOS OCTOGRAMMUS (Pallas).}

Labrax octogrammus PAllas, Zoogr. Rosso-Asiat., III, 1811, p. 283; Kamchatka, Petropaulski and Avatcha Bay. (Coll. Merk.)

Chirus ordinatus Cope, Proc. Amer. Philos. Soc. Phila., 1873, p. 28; Unalaska. (Coll. Prof. Geo. Davidson.)

Hexagrammus ordinatus Jordan and Gilbert, Synopsis, 1883, p. 642.

Octogrammus pallasi Bleek er, Versl. Ak. Amst., VI, 1874, p. 1370; after Pallas. Chirus octogrammus GüNTHER, Cat. II, 1860, p. 92. Chirus octogrammus GüNTHER, Cat.
Hexagrammus octogrammus Jordan and Evermann, Fish. N. M. Am., II, 1898, p.
1869; Unalaska, Petropaulski, Robben, Iturup Island.-Jordan and Ginberr, Rept. U. S. Fur Seal Comm., III, 1898, p. 449, pl. L; same localities.

Head $3 \frac{5}{6}$ in length without caudal; depth $3 \frac{1}{2}$. Dorsal XIX, 24; anal 25. Scales below lateral line 86 to 95 . Eye $5 \frac{1}{4}$ in head; maxillary 3; interorbital (bone only) $7 \frac{9}{4}$. 
Maxillary reaching to below front of pupil. Outer row of teeth enlarged on both jaws; the bands of about equal width on both jaws, much wider in front than on sides; a small patch of teeth on middle of vomer; palatines toothless. A short fringed flap above eye, its length one-half to three-fourths the diameter of eye; no tentacles at nape.

The notch between spinous and soft portions of dorsals of moderate depth; the tips of spines and rays scarcely produced above membrane; the last spine not lengthened beyond the one preceding it; the sixth spine $2 \frac{1}{2}$ in head, equal to the tenth or eleventh spine; the sixth ray $2 \frac{1}{6}$ in head. Pectorals usually reaching just past tips of ventrals, but not nearly to the vertical from vent; its posterior edge broadly rounded; 19 rays, not much branched; the seventh to the tenth rays the longest, $1 \frac{1}{4}$ in head. Anal rays free from membrane at their tips; the fifth ray 3 in head. Ventrals rather long and pointed; their posterior fifth

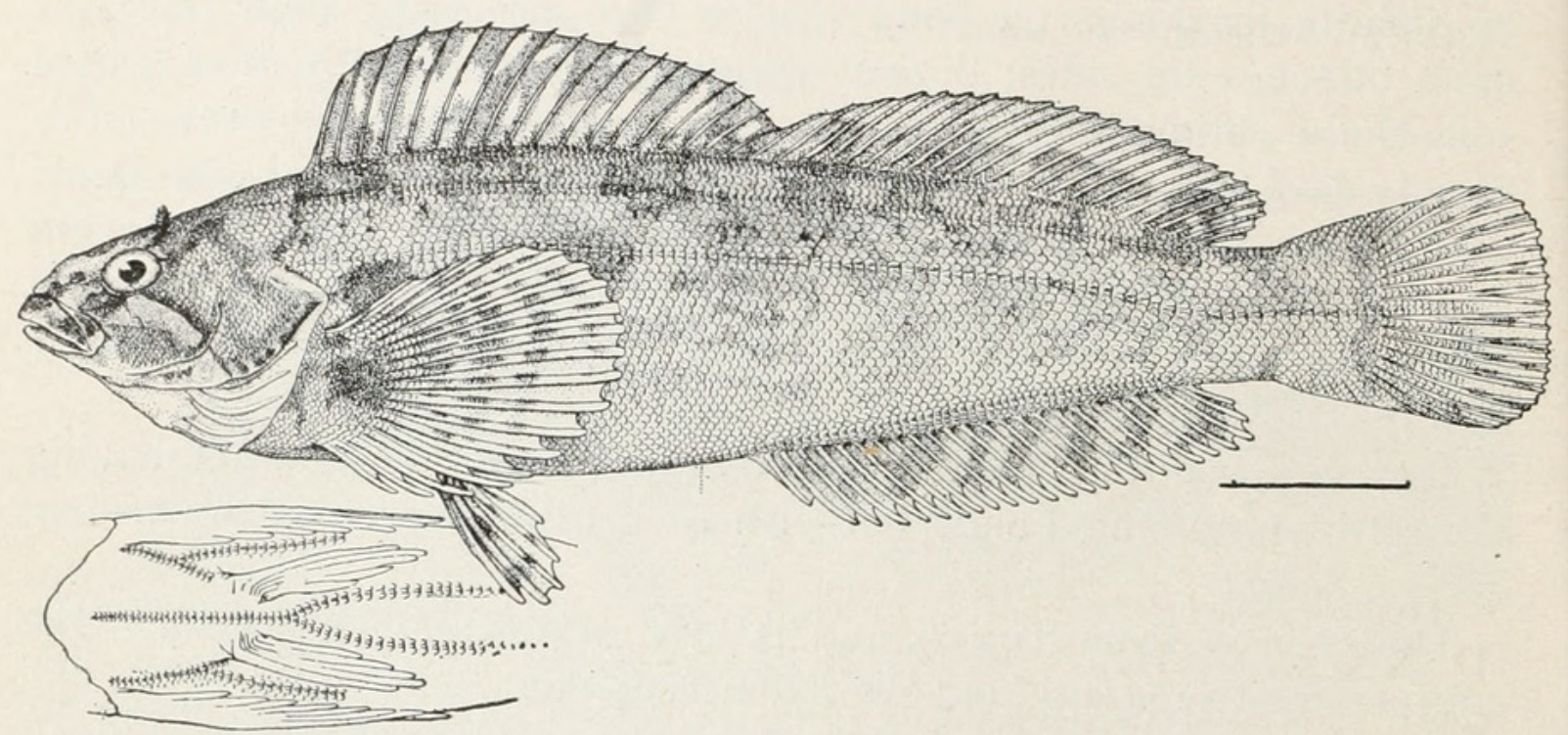

Fig. 2.-Hexagrammos octogramuUs.

extending past the median point between their base and front of anal. Caudal short and broad and very bluntly rounded.

Scales on top of head and on body, except on breast and in front of pectorals, ctenoid; scales on sides of head smooth, slightly imbedded, and not imbricated; scales present at base of soft dorsal, on membrane between rays; and on base of caudal and pectoral, covering the basal half of the former, the basal third of the latter. Snout, maxillary, preorbital, suborbitals, including suborbital stay, mandible, interopercle and branchiostegal regions without scales. A series of scales from front of anal running obliquely upward and forward to dorsal number 47 , distributed as follows: 4 from front of anal to fifth lateral line, 28 to third lateral line, 7 to second lateral line, 4 to first lateral line, and 4 to dorsal. First lateral line united to its fellow of the opposite side at posterior end of cranium and running to under middle of soft dorsal; second line beginning a little behind origin of first and running to upper edge of caudal; the third line as usual from upper part of gill opening to middle of caudal; the fourth forked in front of 
ventrals, the lower part running to base of ventrals, the upper not reaching to tips of ventrals; the median line on breast forked in front of anterior half of ventrals, and running to lower edge of caudal, or sometimes stopping over posterior end of anal.

Uniform dark brown color on back, lighter below; a dark streak along upper edge of suborbital stay, one from eye to tip of snout, one from eye to end of maxillary, one from eye to nape; these only evident in the small examples; a dark, humeral spot; anal uniformly dusky, the tips of the rays white, or in the young crossed by 7 or 8 black bars.

Three large specimens from Hakodate, and numerous small ones from Hakodate and Mororan. This species is abundant from Hokkaido, through the Kurile Islands (Robben Island, Iturup Island) and the Aleutian Islands to Petropaulski and Unalaska.

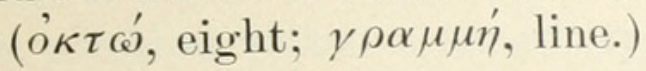

\section{HEXAGRAMMOS LAGOCEPHALUS (Pallas).}

Labrax lagocephalus PALlas, Mém. Ac. St. Petersb., II, 1810, p. 384; Kuril Islands. Grammotopleurus lagocephalus Jordan and Evermans, Check-List Fishes, 1896, p. 435 .

Hexagrammus decagrammus BeAn and BeAn, Proc. U. S. Nat. Mus., 1896, p. 383, specimens from Petropaulski; not of Pallas.

Hexagrammos lagocephalus Jordan and Gilbert, Fishes of Bering Sea, in Rept. U. S. Fur Seal Investigations, 1898, p. 450.-Jordan and Evermann, Fish N. M. Am., II, 1898, p. 1873; Robben I., Bering I., Iturup I.

Head $3 \frac{3}{5}$ to 4 in length; depth $3 \frac{2}{5}$ to $3 \frac{3}{5}$; eye small, about $5 \frac{1}{4}$ in head. D. XX to XXIII, 22 to 24 ; A. 22 to 24 ; P. 20 to 21 . Outer row of teeth enlarged in both upper and lower jaws. Teeth on vomer and front of palatines. Maxillary extending to below middle of eye in adults, $2 \frac{1}{3}$ in head ( $2 \frac{4}{5}$ in young). A small flap above eye, fringed along the margin; no tentacles on nape. Fins high, the spinous dorsal deeply notched, the last spine somewhat longer than the one preceding; in the adult the fifth spine is the longest, nearly $\frac{1}{2}$ length of head, the third and fourth spines nearly equal to the fifth; from the fifth the spines gradually diminish in height to near the end of the fin, when they become rapidly shortened to form the notch. Caudal very broad at base, convex at its posterior margin, even when the fin is closed; pectorals broadly rounded, rather short, the longest rays $1 \frac{1}{4}$ to $1 \frac{1}{5}$ in head, not nearly reaching vertical from vent; ventral fins $1 \frac{2}{3}$ to 2 in head, short and rounded in the young, becoming longer and more pointed in adults; pectoral and ventral rays very broad, especially toward their tips, and much branched; soft rays of dorsal and anal fins cleft on terminal fifth, as in other species, the two halves not diverging; 5 lateral lines on each side as usual, 2 dorsal, a median, and 2 ventral; upper dorsal line continued to beyond middle of second dorsal fin, usually ending under the fourteenth or sixteenth ray; lower 
dorsal line and the median line extended to base of caudal; upper ventral line originating below and in front of the pectoral fin, passing immediately above base of ventral, to which it does not send a separate branch, and terminating opposite middle of anal fin; lower ventral line single on breast, forking in advance of middle of ventral fins, the branches passing to base of caudal. In the young the scales are all ctenoid, except those in mid-ventral region, breast, prepectoral area, and sides of head all becoming smooth in adult; snout, subocular ring, suborbital stay, interopercle, and usually the lowermost portion of subopercle, scaleless; basal half or more of caudal and basal third of soft dorsal with the membranes densely scaled; pectoral basis also densely scaled; scales on breast not greatly reduced, more than half as large as those on middle of sides; median lateral line with 110 pores; 8 or 9 scales in an oblique series between median line and the one above it. Color in most of our specimens a nearly uniform warm brown, lighter on under parts, marked only with irregular small black

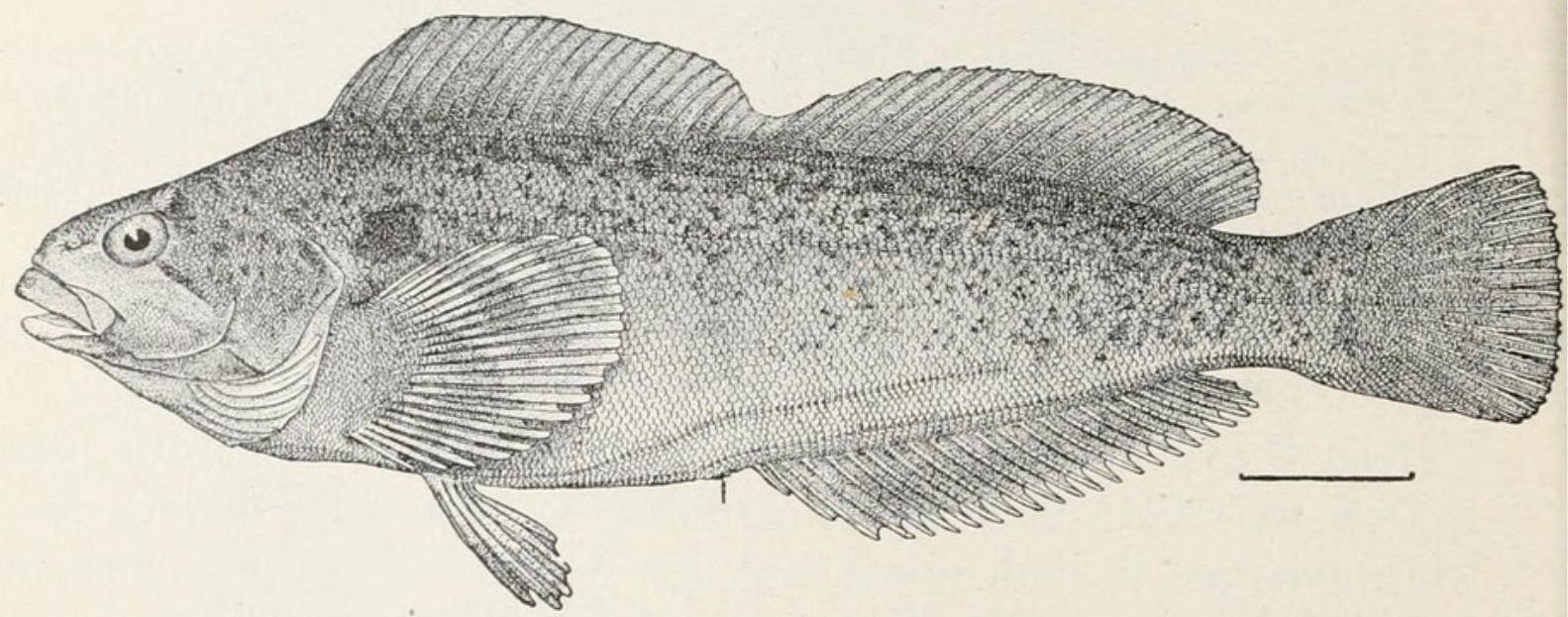

Fig. 3.-HEXagRAMMOS LAGOCEPHALUS.

spots and lines, wnich may extend on the dorsal and pectoral fins; anal and ventrals black, the thickened tips of the rays in these and the pectoral fins often white; a large blackish humeral spot in young specimens, often disappearing in adults. One specimen (Iturup Island) has the upper parts, including dorsal and caudal fins, bright reddish, with some dusky blotches and cloudings, the humeral spot conspicuous.

West shore of Bering Sea; not known from Hokkaido nor from Alaska. We have numerous specimens from Robben Island, one specimen each from Bering and Iturup, islands. Young specimens up to $20 \mathrm{~cm}$. in length have the scales all rough ctenoid as in $H$. stelleri and II. octogrammus. Specimens $30 \mathrm{~cm}$. long have most of the scales smooth, a few along middle of sides still ctenoid. In an adult $54 \mathrm{~cm}$. long all the scales are smooth, those on head and nape partially imbedded. In shape and general appearance this species very much resembles H. octogrammus. It has a deep caudal peduncle, a convexly rounded caudal fin, and a rather bluntly rounded snout.

( $\lambda \alpha \gamma$ ós, hare; $\kappa \varepsilon \phi \alpha \lambda \dot{\eta}$, head.) 


\section{SUMMARY.}

\section{Family Hexagrammide.}

1. Agrammus Günther.

1. agrammus (Schlegel); Tokyo, Aomori, Hakodate.

2. Hexagrammos (Steller) Tilesius.

2. otakii Jordan and Starks; Tokyo, Aomori, Hakodate, Hiroshima, Kobe, Tsuruga, Nagasaki.

3. aburaco Jordan and Starks; Tokyo, Nagasaki, Hakodate.

4. octogrammus (Pallas); Hakodate, Mororan, Robben I., Iturup I.

5. lagocephalus (Pallas); Robben I., Bering I., Iturup I.

Note.-In addition to the species here enumerated, Dr. Peter J. Schmidt records (Faune de la mer du Japon, etc., 1903, p. 15) Pleurogrammus monopterygius (Pallas), from near Vladivostok. This should be added to the known fauna of the Japan Sea. 


\section{$2 \mathrm{BHL}$ Biodiversity Heritage Library}

Jordan, David Starr and Starks, Edwin Chapin. 1903. "A review of the fishes of Japan belonging to the family of Hexagrammidae." Proceedings of the United States National Museum 26(1348), 1003-1013. https://doi.org/10.5479/si.00963801.26-1348.1003.

View This Item Online: $\underline{\text { https://www.biodiversitylibrary.org/item/32571 }}$

DOI: https://doi.org/10.5479/si.00963801.26-1348.1003

Permalink: https://www.biodiversitylibrary.org/partpdf/9463

\section{Holding Institution}

Smithsonian Libraries

\section{Sponsored by}

Smithsonian

\section{Copyright \& Reuse}

Copyright Status: NOT_IN_COPYRIGHT

This document was created from content at the Biodiversity Heritage Library, the world's largest open access digital library for biodiversity literature and archives. Visit BHL at https://www.biodiversitylibrary.org. 